HortSCIENCE 26(1):60-62. 1991.

\title{
Heritability of Leucostoma persoonii Canker Resistance among Diverse Peach Genotypes
}

\author{
Loong S. Chang'and Amy Iezzoni \\ Department of Horticulture, Michigan State University, East Lansing, \\ MI 48824
}

\author{
Gerald Adams \\ Department of Botany and Plant Pathology, Michigan State University, \\ East Lansing, MI 48824
}

Additional index words. Prunus persica, disease resistance

\begin{abstract}
Heritability and the genetic and environmental variance components of resistance to the canker-causing pathogen Leucostoma persoorrii were estimated in a population of diverse peach (Prunus persica L.)- genotypes. Disease resistance was measured as the length of necrotic tissue, i.e., canker length, following artificial inoculation in the field. Genetic and environmental variations were partitioned as variance components of the linear statistical model. Heritability was estimated by regressing average performance of seedlings on performance of their maternal parent. The genetic variance was highly significant, and the heritability for canker necrotic length was relatively high (0.72), suggesting that it should be possible to select $L$. persoonii -resistant individuals within the population.
\end{abstract}

Perennial canker, incited by Leucostoma persoonii Fr. (Nits.) Hohn or L. cincta (Pers, ex Fr.), seriously limits peach longevity and productivity in cold areas of peach production (Cline, 1982; Gairola and Powell, 1970; Hildebrand, 1947; Jones and Luepschen, 1971; Layne, 1976, 1984; Luepschen, 1981; Wensley, 1964). Since cultural practices and chemical treatments do not adequately control the disease, the ultimate approach must be through host-plant resistance. Studies of peach susceptibility to Leucostoma infection, based on either natural infection or artificial inoculation, have been conducted, and almost all commercial peach cultivars failed to show resistance (Dhanvantari, 1978; Dhanvantari and Dirk, 1983; Gairola and Powell, 1970; Hildebrand, 1947; Layne,

Received for publication 2 Mar. 1990. We acknowledge the Michigan Agricultural Experiment Station for their support of this research. We thank Bruce Topp, Wayne Sherman, and Paul Hansche for their review of the manuscript. Funded in part by USDA Contract no. 88-34152-3380 to A.I. The cost of publishing this paper was defrayed in part by the payment of page charges. Under postal regulations, this paper therefore must be hereby marked advertisement solely to indicate this fact.

'Current address: Tao-Yuan District Agriculture Improvement Station, Tao-Yuan, Taiwan, R.O.C.
1984; Luepshen, 1981; Palmiter and Hickey, 1970). Possibly, this lack of resistance to Leucostoma can be attributed to the narrow genetic base of peach cultivars in North America (Layne, 1976, 1984). Where some level of resistance was found, the reaction tended to be inconsistent among experiments. Following inoculation of a diverse peach population with $L$. persoonii, we reported that some peach genotypes may have a higher tolerance to $L$. persoonii canker than has been found previously in U.S. germplasm (Chang et al., 1989).

Studies of various tree crops, including sweet cherry, peach, nectarine, walnut, and plum, have shown considerable additive genetic variance for commercially important traits (Hansche, 1986a, 1986b; Hansche and Boyton, 1986; Hansche et al., 1966; Hansche et al., 1972a; Hansche et al., 1972b; Kester et al., 1977). Estimates of heritability and the relative contributions of genetic and environmental variability are useful to breeders as guides in improving tree crops and in maximizing breeding efficiency.

This study was undertaken to evaluate genetic and environmental variation and to estimate the heritability of $L$. persoonii resistance in a diverse peach population that previously had been shown to segregate for 
Table 1. Parents of the 15 half-sib peach families used to calculate the heritability estimates of $L$. persoonii resistance from parent-offspring regression (POR) and the least squares model (LS).

\begin{tabular}{|c|c|c|c|}
\hline \multirow[b]{2}{*}{ Parent } & \multirow[b]{2}{*}{ Pedigree } & \multicolumn{2}{|c|}{ Model } \\
\hline & & POR & LS \\
\hline Babygold 8 & PI35201 x Ambergem & & $\mathbf{x}$ \\
\hline Canadian Harmony & Redskin $\times$ Sunhaven & $\mathbf{x}$ & $x$ \\
\hline Elberta & Chinese Cling (open-pollinated) & $\mathbf{x}$ & \\
\hline Harken & Redskin $\times$ Sunhaven & $\mathbf{x}$ & $\mathrm{x}$ \\
\hline Loring & Frank $x$ Halehaven & $\mathbf{x}$ & $\mathrm{x}$ \\
\hline Red Hale & Unknown & & $\mathbf{x}$ \\
\hline B8-11-147 & $\begin{array}{l}(\text { K82 } \times \text { Sunrise }) \times[(\text { Red Ceylon } \\
\times \text { NJ191) } \times \text { Okinawa }]\end{array}$ & $\mathbf{x}$ & $\mathrm{x}$ \\
\hline B8-20-171 & $\left(5110417 \times\right.$ Ta Tao $\left.3^{2}\right) \times$ C2R31T45 & & $\mathbf{x}$ \\
\hline B8-21-20 & Orange Cling x RR65-1 & & $\mathbf{x}$ \\
\hline C2-28-89 & Kasna Dupnishka open-pollinated & $\mathbf{x}$ & $\mathrm{x}$ \\
\hline C4-11-97 & Peach $x$ almond & $\mathrm{x}$ & $\mathbf{x}$ \\
\hline NJ257 & Honeydew Hale $x$ Jefferson & & $\mathbf{x}$ \\
\hline NJN69 & $(\mathrm{N} J 555 \times$ NJC68) $\times$ Marzochella & $\mathrm{x}$ & $\mathrm{x}$ \\
\hline NJ672017002 & (PI35321 $\times$ Cherryred) $\times$ Prunus kansuensis & & $\mathbf{x}$ \\
\hline RR37-15 & NJ174 $\times$ Prunus kansuensis & & $\mathbf{x}$ \\
\hline
\end{tabular}

${ }^{2}$ Ta Tao 3 = P.I. 101665.

Table 2. The analysis of variance of the linear statistical model used to calculate the heritability of canker resistance among 14 peach half-sib families.

\begin{tabular}{lcc}
\hline \hline Sources of & & Mean \\
v a r i a t i o n & df & squares \\
\hline Among peach families $\left(\mathrm{F}_{\mathrm{i}}\right)$ & 13 & $179.03^{* * *}$ \\
Progeny within family $\left(\mathrm{P}_{\mathrm{ij}}\right)$ & 68 & $38.48^{*}$ \\
Year $(\mathrm{Y})$, & 2 & 6.28 \\
Year x peach family $(\mathrm{FY})_{\mathrm{in}}$ & 26 & 32.96 \\
Year $\mathbf{x}$ progeny within family $\left(\mathrm{Y} \times \mathrm{P}_{\mathrm{ij}}\right)$ & 136 & $25.02^{* *}$ \\
Sampled branch within progeny & & 8.5 \\
$\quad$ within family $\left(\mathrm{S}_{\mathrm{ijk}}\right)$ & 82 & 13.55 \\
$\mathrm{Y} \times \mathrm{S}_{\mathrm{ijk}}\left(\mathrm{E}_{\mathrm{ikk}}\right)$ & 163 & \\
\hline
\end{tabular}

Significant at $P=0.005,0.01$, and 0.05 , respectively.

Table 3. Mean values of canker necrotic length for open-pollinated progeny generated from eight diverse peach parents.

\begin{tabular}{lcc}
\hline \hline Parent & $\begin{array}{c}\text { Parent canker } \\
\text { necrotic length } \\
(\mathrm{cm})\end{array}$ & $\begin{array}{c}\text { Offspring canker } \\
\text { necrotic length } \\
\left(\mathrm{cm}^{\mathrm{y}}\right)\end{array}$ \\
\hline NJN69 & 13.5 & 11.1 \\
Elberta & 13.1 & 12.8 \\
Harken & 11.0 & 9.4 \\
Loring & 10.3 & 9.6 \\
Canadian Harmony & 9.7 & 8.3 \\
C2-28-89 & 9.3 & 9.4 \\
B8-11-147 & 8.3 & 7.4 \\
C4-11-97 & 5.1 & 5.7 \\
\hline
\end{tabular}

${ }^{2}$ Mean of 10 clones over 2 years. The performance of female parent was estimated by the mean of the necrotic length ratings from 10 replicated clones following inoculations in Fall 1986 and 1987.

'Mean of 20 progeny per clone over 2 years.

L. persoonii resistance. Genetic and environmental variations were partitioned as variance components of the linear statistical model. Heritability was estimated from the linear regression of offspring performance on the average performance of its female parent.

Linear statistical model. Open-pollinated seedlings from diverse backgrounds were planted in Spring 1984 in a completely randomized design at the Horticultural Research Center, East Lansing, Mich. (Chang et al., 1989). Fourteen open-pollinated peach families with at least six progeny were randomly selected to estimate the heritability of $L$. persoonii resistance (Table 1).

Two 2-year-old branches, $\approx 17 \mathrm{~mm}$ in di-
$+E_{i \mathrm{jk}}$, where $\mathrm{Y}_{\mathrm{i} \mathrm{jk}}$, represents the kth sample branch within the jth progeny within the ith peach family in the lth year. The effects in this model stand for the overall population mean $(\mathrm{u})$, a random effect due to each family $\left(\mathrm{F}_{\mathrm{i}}\right)$, the effect of progeny within family $\left(\mathrm{P}_{\mathrm{ij}}\right)$, the effect of sampling branches within progeny within peach family $\left(S_{i j k}\right)$, the year effect $\left(Y_{1}\right)$, the interaction of family and year $\left[(\mathrm{FY})_{\mathrm{il}}\right]$, and the error due to the year $\times \mathrm{S}_{\mathrm{i} k \mathrm{k}}$ $\left(\mathrm{E}_{\mathrm{ijk}, \mathrm{k}}\right)$.

Parent-offspring regression. Eight randomly selected female parents from the original population (Chang et al., 1989) were grafted onto Tennessee Natural peach rootstock and planted in 1985 in blocks adjacent to the orchard of diverse peach progeny (Table 1). Ten grafted trees per female parent plus 20 open-pollinated progeny per female parent were selected for artificial inoculation. Two randomly selected healthy branches of each grafted tree and each progeny were inoculated on the same day in 1986 and 1987 as described above. Female parent performance was rated as the mean canker length of 10 replicated individuals over 2 years. Progeny performance from the eight families was calculated as mean canker length over the two years.

Results were based on unadjusted data for the year effect because no significant variation due to year effect was evident in previous studies (Chang et al., 1989). Heritability was based on the regression of the mean performance of their maternal parent.

Linear statistical model. The experimental error can be divided into the error due to year $\mathrm{x}$ sampling branches within progeny within family $\left(\mathrm{E}_{\mathrm{ikk}}\right)$ and that due to sampling branches within progeny within family $\left(S_{i j k}\right)$ (Table 2 ). The variation due to sampling error was not significant. The attempt to choose branches of equal size may have effectively controlled this potential source of variation. However, the second error term was quite large. This variation could be attributed to branch size, age, and directional orientation that may have interacted differently between years.

Variation attributed to years and the interaction between year and peach family were not significant and, therefore, would not dramatically decrease the efficiency of selection of more disease-resistant individuals from this population. However, the year $\times$ progeny within family variation was relatively large. Therefore, statistically removing the yearly environmental effect would increase the selection efficiency and the rate of genetic gain.

The variation due to the progeny within family was significant. Doubtless, this variation for peach families was due to a combined effect of genetic segregation within the families and environmental variability. Therefore, it is not appropriate to estimate how much variability is due to the environmental effect within families without clonal propagation and replicated evaluation of the individual seedlings. The mean squares due to variation among peach families were highly significant, indicating a large genetic component for canker length in this population. 
Parent-offspring regression. The parentoffspring regression is commonly used to estimate the heritability of quantitative traits in various crop species. Progeny mean values are usually regressed on values from one or both parents, depending on pollination control. Since peach is presumably highly selfpollinated (Hesse, 1976), the performance of the female parent has been used as an estimate of the mid-parent performance (Hansche, 1968a, 1968b). The linear regression coefficient gives the estimate of heritability as the ratio of additive genetic variance : phenotypic variance.

Generally, the mean canker necrotic length rating was lower in the seedling population than in the female parent performance over the two years of observations (Table 3 ). The apparent increase in resistance to $L$. persoonii in the progeny may have been due to self-pollination increasing the additive effect or, alternatively, to an effect of age or grafted vs. own-rooted trees. The heritability estimate and standard deviation, based on parent-offspring regression of the canker necrotic length ratings, were $0.76 \pm 0.11$. According to Falconer (1981), use of the parent performance will cause the heritability estimate to be biased downward by $\approx 5 \%$. Therefore, the heritability of $L$. persoonii resistance in this diverse population can be calculated as $0.76 \times 0.95=0.72$. This relatively high heritability estimate is consistent -with the highly significant genetic component (variation among peach families) from the linear statistical model.

Several factors influence the breeder's selection of a breeding scheme to improve genetic stocks. These include: 1) quantity and types of genetic variance, 2) environmental effects, 3) the interaction between environment and genotype, and 4) linkage effects. Genetic and environmental effects and interactions between genotype and environment were estimated in this population. The estimate of heritability for $L$. persoonii resistance, measured as canker length, was relatively high. Therefore, it should be possible to select $L$. persoonii -resistant individuals in this population and maintain them in the breeding program without the masking effect of year $\mathrm{X}$ year variation.

\section{Literature Cited}

Chang, L.S., A. Iezzoni, G. Adams, and G.S Howell. 1989. Leucostoma tolerance and cold hardiness among diverse peach genotypes. J. Amer. Soc. Hort. Sci. 114:482-485.

Cline,R.A.1982.Culturalpractices in peach canker development in Ontario. Proc. Stone Fruit Decline Workshop, 18-20 Oct., Michigan State Univ., East Lansing.

Dhanvantari, B.N. 1978. Cold predisposition of dormant peach twigs to nodal cankers caused by Leucostoma spp. Phytopathology 68:17791783

Dhanvantari, B.N. and V.A. Dirks. 1983. An evaluation of peach cultivars and selections for resistance to Leucostoma cincta. Can. J. Plant Sci. 63:307-310.

Falconer, D.S. 1981. Introduction to quantitative genetics. 2nd ed. Longman, N.Y. p. 148-169.

Gairola, C. and D. Powell. 1970. Cytospora peach canker in Illinois. Plant Dis. Rptr. 54:832-835.
Hansche, P.E. 1986a. Heritability of fruit quality traits in peach and nectarine breeding stocks dwarfed by the $d w$ gene. HortScience 21:11931195 .

Hansche, P.E. 1986b. Heritability of juvenility in peach. HortScience 21:1197-1198.

Hansche, P.E. and B. Boyton. 1986. Heritability of enzymatic browning in peach. HortScience 21:1195-1197.

Hansche, P. E., V. Beres, and R.M. Brooks. 1966. Heritability and genetic correlation in the sweet cherry. Proc. Amer. Soc. Hort. Sci. 88:173 183.

Hansche, P. E., V. Beres, and H.I. Forde. 1972a. Estimates of quantitative genetic properties of walnut and their implications for cultivar improvement. J. Amer. Soc. Hort. Sci. 97:279 285.

Hansche, P. E., C.O. Hesse, and V. Beres. 1972b. Estimate of genetic and environmental effects on several traits in peach. J. Amer. Soc. .Hort. Sci. 97:76-79

Hesse, C.O. 1975. Peach, p. 285-331. In: J. Janick and J.N. Moore (eds.). Advances in fruit breeding. Purdue University Press, West Lafayette, Ind

Hildebrand, E.M. 1947. Perennial peach canker and the canker complex in New York with methods of control. Cornell Univ. Agr. Expt.
Sta. Memorandum 276:61.

Jones, A.C. and N.S. Luepschen. 1971. Seasonal development of Cytospora canker on peach in Colorado. Plant Dis. Rptr. 55:314-317.

Kester, D.E., P.E. Hansche, V. Beres, and R.N Asay. 1977. Variance components and heritability of nut and kernel trait in almond. J. Amer. Soc. Hort. Sci. 102:264-266.

Layne, R.E.C. 1976. Influence of peach seedling rootstock on perennial canker of peach. HortScience 11:509-511.

Layne, R.E.C. 1984. Breeding peaches in North Americafor cold hardiness and perennial canker (Leucostoma spp.) resistance-Review and outlook. Fruit Var. J. 38:130-136.

Luepschen, N.S. 1981. Criteria for determining peach variety susceptibility to Cytospora canker. Fruit Var. J. 35:137-140.

Palmiter, D.H. and K.D. Hickey. 1970. Relative resistance of 26 peach cultivars to bacteria spot and Valsa canker. Plant Dis. Rptr. 54:395-399.

Scorza, R. and P.L. Pusey. 1984. A wound-freezing inoculation technique for evaluating resistance to Cytospora leucostoma in young peach trees. Phytopathology 74:569-572.

Wensley, R.N. 1964. Occurrence and pathogenic ityof Valsa (Cytospora) species and other fungi associated with peach canker in southern Ontario. Can.J. Bet. 42:841-857. 